\title{
KOTI KATKAISUHOIDON TILANA
}

\author{
Suvi Holmberg: YTT, yliopistonlebtori, Tampereen yliopisto \\ Johanna Ranta: YTT, tutkijatohtori, Tampereen yliopisto
}

suvi.holmberg@tuni.fi; johanna.ranta@tuni.fi

Janus vol. 29 (1) 2021, 54-70

\section{Tiivistelmä}

Tässä artikkelissa kysymme, miten koti tilana tukee ja haastaa psykososiaalisesti orientoituneen katkaisuhoidon käytäntöjä. Tutkimuksen metodologinen kehys nojaa kodin maantieteen perinteeseen. Lähestymme kotia monimerkityksellisenä kulttuuristen, materiaalisten, emotionaalisten ja sosiaalisten merkitysten läpäisemänä tilana. Tutkimusaineisto on kerätty vuonna 2018 liikkuvalla etnografialla suomalaisesta kotikatkopalvelusta. Se koostuu kahdeksalla kotikäynnillä nauhoitetusta asiakas-työntekijävuorovaikutuksesta. Tutkimus havainnollistaa, kuinka kotia merkityksellistetään paitsi asiakkaan yksityisenä tilana, myös päihdetyön toteuttamisympäristönä. Koti elementteineen ja rutiineineen luo turvallisen ja häpeältä suojaavan sekä autonomiaa ja tukea antavan tilan juomisen lopettamiselle, mutta edellyttää asiakkaalta tietoisuutta tilaan liittyvistä juomista laukaisevista tekijöistä sekä omasta vastuustaan osana kotona toteutettavaa katkaisuhoitoa.

\section{JOHDANTO}

Katkaisuhoito on perinteisesti yhdistetty kliiniseen terveydenhuoltoon ja laitosolosuhteisiin - lääkkeisiin, katkaisuhoitoasemiin ja sairaaloiden vuodeosastoihin. Laitoskatkaisuhoidolla onkin vakiintunut asema suomalaisessa päihdehoitojärjestelmässä (esim. Kuussaari ym. 2012).Vuonna 2017 jo pelkästään päihdehuollon erityispalveluiksi määritetyillä katkaisuhoitoasemilla rekisteröitiin lähes 9300 asiakasta ja yli 80000 hoitovuorokautta (Terveyden ja hyvinvoinnin laitos 2018, 64). Vahvuudeksi tällaiselle lääketieteellisesti ohjatulle, valvotuissa laitosolosuhteissa toteutetulle ja intensiiviselle laitoskatkaisuhoidolle voidaan lukea ympäristön turvallisuus, sillä tukea vieroittautumiseen on saatavilla ympärivuorokautisesti. Katkaisuhoitoon hakeutumisessa on kuitenkin myös kulttuurisesti määrittynyt puolensa: päihteiden ongelmakäyttö on herkästi stigmatisoitu ilmiö, mikä voi aiheuttaa häpeää ja vaikuttaa halukkuuteen asioida päihdepalveluissa (esim. Vesa ym. 2017). Lisäksi palveluihin hakeutumista voivat hankaloittaa pitkät välimatkat niiden luokse (Babor ym. 2009; Samposalo ym. 2018), liikkumisen esteet sekä taloudellinen niukkuus.

Suomessa on ollut tavoitteena rakentaa helposti saavutettava, asiakkaille tarkoituksenmukainen ja kustannustehokas päihdehoitojärjestelmä (esim. Babor ym. 2009). Katkaisuhoidon jalkauttaminen asiakkaiden koteihin on yksi 
keino saavuttaa näitä tavoitteita. Kotona toteutettava katkaisuhoito, jota tässä artikkelissa kutsumme kotikatkoksi, on lisääntynyt Suomessa 2010-luvulta lähtien. Kotikatkoa on kehitetty joissakin kunnissa pilottitoimintana, joka sittemmin on vakiinnuttanut asemaansa yhtenä päihdetyön muotona (esim. Pesonen 2010; Tuominen 2014; Koivisto 2018). Tämän lisäksi kotikatkoa tarjoavat jotkin yksityiset palveluntuottajat. Käytännössä kotikatkopalveluiden variaatio on laaja: niiden kesto ja kotikäyntien tiheys vaihtelevat useista päivittäisistä käynneistä muutamia kertoja kuussa tapahtuviin käynteihin. Lisäksi palveluiden sisällöt vaihtelevat lääkkeellisestä katkaisuhoidosta lääkkeettömään ja psykososiaalista orientaatiota painottavaan katkaisuun ja sitä tukevaan kuntouttavaan hoitoon. (Esim. Pesonen 2010; Tuominen 2014; Koivisto 2018.)

Tässä tutkimuksessa tarkastelemamme kotiin vietävä psykososiaalinen alkoholikatkaisuhoito poikkeaa perinteiseksi mielletystä katkaisuhoidosta, jonka tarkoituksena on lievittää ja poistaa vieroitusoireita ensisijaisesti lääkehoidolla. Psykososiaalisen orientaation lähtökohtana on asiakkaan elämäntilanteen huomioiminen ja tukeminen kokonaisvaltaisesti heti vieroittautumisen alusta lähtien (esim. Granfelt 1993; Toikko 1997; Weckroth 2007). Asiakkaiden usein kompleksisten elämäntilanteiden vuoksi lääketieteellisesti ohjattu katkaisuhoito tarvitseekin muun päihdehoidon tavoin rinnalleen psykososiaalista orientaatiota (ks. Kuusisto \& Ranta 2020).

Koti on ollut sosiaalityön ja muun yhteiskuntatieteellisen tutkimuksen kohteena ajankohtainen Suomessa jo pitkään (esim. Granfelt 1998; Janus 3/2000; Jokinen 2010; Vilkko ym. 2010; Juhila ym. 2016; Forsberg \& Ritala-Koskinen 2018). Kotikatkotoimintaa ei kuitenkaan ole sen yleistymisestä huolimatta tutkittu juuri lainkaan, sillä se on vielä varsin tuore palvelumuoto (jalkautuvan päihdetyön kehittämisestä ks. Vesa ym. 2017). Sen sijaan kansainvälisesti ihmisten elinyhteisöihin ja koteihin jalkautuva päihdetyö on kiinnostanut tutkijoita jo 1980-luvulta lähtien (Bischof ym. 2003, 18-20). Kotikatkon funktiota, kuten sen tarpeen arviointia ja sopivuutta, hoidollista ja taloudellista vaikuttavuutta sekä hyötyjä ja haittoja on tarkasteltu systemaattisin kirjallisuuskatsauksin (Fleeman 1997; Nadkarni ym. 2017). Lisäksi on eritelty asiakkaiden, läheisten ja ammattilaisten kokemuksia ja näkemyksiä kotikatkosta (Stockwell 1990; Roshe ym. 2001; Carlebach ym. 2011; Wright ym. 2018) sekä tarkasteltu erilaisten terapiamenetelmien kuten psykologisen intervention (Alwyn ym. 2004) ja ratkaisukeskeisen perheterapian (Bischof ym. 2003) mahdollisuuksia osana kotikatkoa. Kodin tilan erityisyys katkaisuhoidon ympäristönä jää näissä tutkimuksissa kuitenkin lähes näkymättömäksi tutkimuksellisen fokuksen kiinnittyessä eri toimijoiden kokemuksiin palvelusta tai sopiviin työmenetelmiin. Tähän puutteeseen pyrimme artikkelissamme vastaamaan kysymällä: Miten koti tilana tukee ja haastaa psykososiaalisesti orientoituneen katkaisuhoidon käytäntöjä ja asiakaskohtaamisia? Löytääksemme vastauksia kysymykseemme on koputettava oveen ja astuttava kodin seinien sisäpuolelle. 


\section{MONIMERKITYKSELLINEN KOTI}

Suomalaisessa alkoholinkäyttökulttuurissa kodilla on monimerkityksellinen asema. Se on sekä paikka, joka päihteistä riippuvaisilta voi puuttua (esim. Granfelt 1998) että tila, jossa kansalaiset useimmiten juovat (Mustonen \& Österberg 2010; Warpenius \& Mäkelä 2018). Vuonna 2016 toteutetun Juomatapatutkimuksen mukaan suomalaisten humalajuomisesta noin kaksi kolmasosaa ja muusta alkoholinkäytöstä noin neljä viidesosaa tapahtuu omassa tai jonkun toisen ihmisen kodissa. Tyypillisintä kotona juominen on ikääntyneemmille ihmisille. Vaikka kotona juodaankin yleisimmin puolison seurassa, on koti toisaalta myös tavallisin ympäristö yksin juomiselle. (Warpenius \& Mäkelä 2018.) Kodin merkitys on viime aikoina korostunut myös psykososiaalisen työn ja institutionaalisten kohtaamisten ympäristönä, kun trendinä on ollut lisätä ja kehittää erilaisia jalkautuvia päihde- ja mielenterveyspalveluita (esim. Haahtela \& Juhila 2016; Vesa ym. 2017; Juhila 2018, 139-164).

Lähestymme tutkimuksessamme kotia tilana, jolla on paitsi fyysiset elementtinsä, kuten esineensä ja sijaintinsa, myös (usein tiedostamattomat) ajalliset rytminsä sekä kulttuuriset, sosiaaliset ja moraaliset järjestyksensä, jotka vaikuttavat ihmisten toimintaan (Douglas 1991; Dyck ym. 2005, 174-175). Koti ilmentää paitsi asiakkaan asumisen materiaalista ympäristöä, myös henkilökohtaisia muistoja, tunteita, rutiineja, erilaisia elämänhistorioita sekä kulttuurisia ja läheissuhteissa ilmeneviä oletuksia käyttäytyä tai toimia tietyllä tavalla. Siksi koti voi muodostua myös valta-asetelmien ja alistamisen (Doug- las 1991) ja pahan tekemisen (Hurtig \& Laitinen 2000) paikaksi. Koti on vahvan yksityinen tila, johon kiinnitytään emotionaalisesti (Ranta \& Juhila 2020). Siihen liitetään ajatuksia niin intiimiydestä, eheydestä ja turvallisuudesta kuin rikkonaisuudesta ja turvattomuudestakin (esim. Granfelt 1998; Vilkko 2000; Dyck ym. 2005; Juhila 2018, 164). Siksi tapahtumiin kotien sisällä voi olla ulkopuolelta hankala puuttua.

Monimerkityksellisyytensä vuoksi kodilla on erityinen luonteensa psykososiaalisen työn ja institutionaalisten kohtaamisten ympäristönä. Kun perinteisesti julkisissa tiloissa toteutuneet palvelukohtaamiset viedään asiakkaan kodin seinien sisäpuolelle, yksityisyys murtuu ja julkinen pääsee sisälle - koti toisin sanoen institutionalisoituu (Milligan 2003; Dyck 2005; Haahtela \& Juhila 2016; Juhila 2018). Kotikatkon yhteydessä näin tapahtuu, kun päihdetyötyöntekijät erilaisine työvälineineen astuvat kodin kynnyksen yli. Samalla yksityisen ja julkisen rajat tulevat lähemmäs toisiaan. Astuminen kodin intiimiin tilaan muuttaa institutionaalisen kohtaamisen ja vuorovaikutuksen luonnetta asiakasjohtoisemmaksi (esim. Juhila ym. 2018, 157-164; Ranta \& Juhila 2020), mikä tekee myös jalkautuvan päihdetyön tutkimisesta kiinnostavaa: katkaisuhoidon voi olettaa saavan erityisiä piirteitä, kun se viedään perinteisestä laitosympäristöstään yksityiseen, henkilökohtaisten muistojen ja tapahtumien värittämään ja asiakkaiden kontrolloimaan tilaan, jossa suomalaiset yleisimmin juovat. 


\section{Metodologia ja Aineisto}

Artikkeli on osa Kodeissa tapahtuvien palvelukohtaamisten maantiede hyvinvointipalvelujen marginaalissa Suomessa ja Ruotsissa -tutkimushanketta (Suomen Akatemia, 2017-2022), jossa keskitytään kodeissa tapahtuvien päihde- ja mielenterveystyön palvelukohtaamisten, kodin tilan sekä asiakas-työntekijävuorovaikutuksen tutkimiseen. Metodologisesti kiinnitymme kodin maantieteen perinteeseen. Kodin maantiede analyysimme lähtökohtana tarkoittaa sitä, että tulkinnassamme kotikatkon kohtaamiset rakentuvat kodin kulttuuristen, materiaalisten, fyysisten, emotionaalisten ja sosiaalisten elementtien kautta (esim. Blunt 2005; Dyck 2005). Nämä elementit tulevat osaksi asiakkaiden koteihin paikantuvaa asiakas-työntekijävuorovaikutusta (esim. Juhila ym. 2016; Raitakari ym. 2018; Ranta \& Juhila 2020). Toisin sanoen koti institutionaalisten kohtaamisten ympäristönä tulee asiakkaiden ja työntekijöiden välisessä vuorovaikutuksessa puhutuksi läsnä olevaksi (Raitakari \& Juhila 2016, 57).

Tutkimusaineisto on kerätty Suomessa vuonna 2018 hyödyntämällä liikkuvan etnografian menetelmää (esim. Büscher \& Urry 2009; Novoa 2015). Metodi eroaa perinteisemmästä instituutioihin paikantuvasta etnografiasta erityisesti siten, että se perustuu tutkijan ja havainnoitavan institutionaalisen toiminnan liikkuvuuteen. Liikkuvalla etnografialla tavoitellaan tietoa etenkin siitä näkökulmasta, millaisia suhteita vuorovaikutuksen osapuolet muodostavat sanallisessa ja ei-sanallisessa vuorovaikutuksessaan kohtaamispaikkaansa (Büscher \& Urry 2009, 104-105). Tä- män vuoksi metodi tarjoaa relevantteja välineitä juuri kodeissa tapahtuvien asiakas-työntekijäkohtaamisten tutkimiseen. Käytännössä liikkuvan etnografian soveltaminen tarkoitti tutkimuksessamme sitä, että tutkija jalkautui kotikatkon päihdetyöntekijöiden ${ }^{1}$ mukana asiakkaiden koteihin nauhoittaen asiakkaiden ja työntekijöiden kohtaamisia sekä kirjaten tarkat havaintonsa kohtaamisista ja kotiympäristöistä kenttäpäiväkirjaan (ks. myös Ferguson 2016; Lydahl ym. 2020).

Tässä artikkelissa aineistonkeruun kontekstina toimiva kotikatkopalvelu on sosiaalihuollon alainen palvelu, joka on suunnattu ainoastaan alkoholia käyttäville aikuisasiakkaille, jotka tarvitsevat tukea päihteiden käytön katkaisemiseen. Palvelu perustuu psykososiaaliseen orientaatioon ja säännöllisiin kotikäynteihin, joiden tiheydestä ja tuen kestosta sovitaan yhteisesti asiakkaan kanssa. Kotikatkon toiminta on pääsääntöisesti lääkkeetöntä, mutta työntekijöiden on mahdollista konsultoida lääkäriä tarvittaessa esimerkiksi laboratoriokokeiden ottamiseksi tai Antabus-lääkityksen aloittamiseksi. Lääkkeettömyys ei myöskään ole kotikatkon edellytys vaan asiakkailla voi olla lääkityksiä, jotka on aloitettu toisen hoitotahon toimesta. Osa kotikatkon asiakkaista tähtää täysraittiuteen, osa alkoholin kohtuukäyttöön. Palvelulla pyritään tavoittamaan erityisesti niitä ihmisiä, joilla ei ole tarvetta tai halua laitoskatkaisuhoidolle tai joille laitospalvelut ovat vaikeasti tavoitettavissa. Asiakkaat päätyvät kotikatkon asiakkaiksi usein eri yhteistyökumppanien avulla, mutta saattavat ottaa yhteyttä palveluun myös itse. 
Kokonaisuudessaan kotikatkokäyntejä tehtiin aineistonkeruun aikana 11, viiden eri asiakkaan luokse. Kahdeksan käyntiä nauhoitettiin ja niistä tehtiin tarkat kenttämuistiinpanot. Kolmesta käynnistä tehtiin vain kenttämuistiinpanot, koska nauhoittaminen ei tuntunut asiakkaasta luontevalta. Tämän artikkelin aineistona hyödynnämme kahdeksaa nauhoitettua kotikatkokäyntiä, sillä keskittymällä luonnollisiin kotikatkovuorovaikutustilanteisiin uskomme pääsevämme parhaiten kiinni merkityksiin, joita koti asiakkaiden ja työntekijöiden välisissä keskusteluissa katkaisuhoidon tilana saa. Nauhoitettuja kotikatkokäyntejä tehtiin neljän eri asiakkaan luokse, joista kolmen luona käytiin kerran ja yhden luona viisi kertaa. Kotikäyntien lukumääräistä vaihtelevuutta selittää kotikatkoprosessin asiakaslähtöisyys: osa asiakkaista toivoi tapaamisia tiiviimmin ja useammin kuin toiset. Asiakkaista yksi oli nainen ja kolme miehiä. Yhdellä kotikatkokäynnillä myös asiakkaan puoliso oli läsnä. Nauhoitettujen kotikäyntien kestot vaihtelivat $35-50$ minuutin välillä ja ajallisesti nauhoitettua aineistoa kertyi yhteensä 6 tuntia ja 22 minuuttia. Litteroitua materiaalia on koossa 124 sivua.

Ennen aineistonkeruun alkua Tampereen alueen ihmistieteiden eettinen toimikunta antoi puoltavan lausunnon tutkimuksen toteuttamisesta. Asiakkaat ja työntekijät allekirjoittivat tutkimusta koskevat suostumuslomakkeet ja heitä informoitiin osallistumisen vapaaehtoisuudesta sekä mahdollisuudesta keskeyttää osallistumisensa milloin tahansa ilman, että se vaikuttaisi kotikatkon asiakkuuteen. Kieltäytymis- ja keskeyttämismahdollisuuden korostaminen näh- tiin tärkeänä erityisesti kotiympäristön sensitiivisyyden vuoksi sekä siksi, että päihteistä riippuvaisten elämäntilanteet voivat olla herkästi haavoittuvia ja tutkimukseen osallistumisen mahdollisia negatiivisia vaikutuksia asiakkaiden arkeen haluttiin ehkäistä. Aineiston analyysissa olemme kiinnittäneet erityistä huomiota aineisto-otteiden anonymisointiin ja kaikki paikkakuntien, ihmisten ja palveluiden nimet on muutettu sekä muut tunnistettavuutta lisäävät seikat on häivytetty.

\section{ANALYYSIPROSESSI}

Analyysiprosessi jakautuu kolmeen vaiheeseen. Ensimmäiseksi latasimme litteroidun aineiston analyysiohjelma ATLAS.ti 8.0:aan ja tarkastelimme huolellisesti, mitä erityistä koti katkaisuhoidon tilana merkitsee. Sovelsimme analyysissa koodauksen menetelmää, jonka perusajatuksena on analyysin vaiheittainen syventäminen yksinkertaisen kuvailun tasolta kohti yksityiskohtaisempaa merkitysten tarkastelua (Gibbs 2007, 41-44), joka tutkimuksessamme todentuu yksityiskohtaisena vuorovaikutuksen analyysina. Koodasimme aineistosta ensin erilleen sellaisen puheen, jossa viitattiin kotiin ja sen lähiympäristöön konkreettisesti. Nimesimme koodaukset "täälä-puheeksi" (yhteensä 73 koodia, 88 sivua), joka koostuu viittauksista kodin fyysisessä tilassa olemiseen (esim. "Sulla on aikamoinen varasto täällä [lääkkeitä]"), toimintaan kodissa (esim. "Sillon mä istun tässä [nojatuolissa]") sekä kodin lähiympäristöön (esim. "Se [päivätoimintapaikka] on tuossa K-kaupan vastapäätä siinä”). Täällä-puheen runsaus koko aineistossa vakuutti meidät siitä, 
että asiakkaan koti ja sen lähiyhteisöt ovat vahvasti läsnä kotikatkon asiakkaiden ja työntekijöiden kohtaamisissa, ja tulkitsimme niistä keskustelemisen keskeiseksi osaksi psykososiaalisesti orientoitunutta kotikatkoprosessia.

Analyysin toisessa vaiheessa syvensimme analyysia identifioimalla kodin läsnäoloa havainnollistavasta täälläpuheesta kaksi erillistä koodia, joihin peilaten kotia merkityksellisestään katkaisuhoidon toteuttamisympäristönä: kodin elementit (49 koodia, 38 sivua) ja päihdetyön käytännöt (44 koodia, 38 sivua). Kodin elementit -koodi sisälsi konkreettisia viittauksia kodin fyysisyyteen ja materiaalisuuteen, kuten huonekaluihin, valokuviin tai muihin esineisiin (esim. ’Joo. Sopiiko et mä pistän vähän pienemmälle tota [televisiota]) sekä sen emotionaalisiksi tulkittaviin elementteihin, kuten suruun, häpeään tai iloon osana vuorovaikutusta (esim. "Ei se kivalta tunnu, mut kai se siinä sitten menee [puolison kuolinpesän asioiden selvittäminen]”). Päihdetyön käytännöt -koodi sisälsi kotona tapahtuvaa päihteiden käyttöä käsittelevän puheen, kuten juomiseen liittyvät kysymykset sekä konkreettisen toiminnan, kuten puhalluttamisen. Lisäksi koodiin kuului palveluohjaus, kuten jatkohoitovaihtoehdoista keskusteleminen. Kodin elementit ja päihdetyön käytännöt -koodit osoittivat, kuinka asiakkaan kodista tuli kotikatkon myötä jännitteinen tila, jossa päihdetyön konkreettiset käytännöt ja asiakkaan henkilökohtainen arki kohtasivat.

Analyysin edetessä huomasimme, kuinka tekemämme koodaukset linkittyivät tiiviisti yhtäältä kodin tarjoamaan tukeen että sen luomiin haasteisiin kat- kaisuhoidon toteuttamisympäristönä. Tämän vuoksi analyysiprosessin kolmannessa vaiheessa täällä-puhe koodattiin vielä kertaalleen suhteessa siihen, kuinka koti tukee (68 koodia, 21 sivua) ja haastaa (26 koodia, 48 sivua) katkaisuhoitoa. Kodin elementit sekä päihdetyön käytännöt -koodit linkittyivät tiiviisti tukea ja haasteita heijastavaan puheeseen ja toimivat välineinä analyyttisen tulkinnan syventämisessä (ks. myös Gibbs 2007), minkä vuoksi rakensimme yksityiskohtaisen vuorovaikutuksen analyysimme näiden näkökulmien varaan. Tukea antaviksi elementeiksi muodostuivat esimerkiksi kodin positiivinen kommentointi ja sen turvallisuus, haasteiksi esimerkiksi kotiympäristön ahdistavuus tai naapurustossa juovat ihmiset. Havainnollistamme seuraavaksi tulkintojamme tarkemmin kuuden aineisto-otteen avulla.

\section{KOTI KATKAISUHOITOA TUKEVANA}

JA HAASTAVANA TILANA

\section{Kodin elementit ja katkaisuhoito}

Kynnystä ylitettäessä kodista esineineen tulee kotikatkokäynnillä usein "jutun juuri", joka tarjoaa sekä tukea tuottavan lähtökohdan kohtaamiselle että haastaa perinteiset työntekijän ja asiakkaan positiot, kun työntekijä astuu asiakkaan henkilökohtaiseen tilaan. Tätä havainnollistaa seuraava esimerkki, jossa työntekijä on juuri ylittämässä Markuksen kodin kynnystä ensimmäisellä kotikatkokäynnillä:

Työntekijä: No niin, me [työntekijä ja tutkija] tullaan sitten ihan vähän peremmälle. Markus: Joo, tervetuloa.

Työntekijä: Sulla on täällä kiva koti. 
Markus: Joo, mä oon yrittäny tätä pitää sillain, tai ollu kuus vuotta, tää on ihan täysin mun itte sisustama ja kaikkee.

Työntekijä: Just joo, no niin. Tää on niin kiva. Mihin sopii istua?

$[\ldots]$

Työntekijä: Tää on ainakin ihan ok. No niin. Onks sul Markus antaa paperia, saanko ottaa tästä yhden paperin?

Markus: Saat.

Työntekijä: Mitä sinulle nyt oikein kuuluu?

Markus: Ihan ok nyt tällä hetkellä kuuluu. Kun sain, oon ollu pari päivää silleen selvänä, siis et ei oo joko krapulassa tai humalassa.

Julkisten tilojen kohtaamisille tavanomaiset asiakas-työntekijäpositiot muuttuvat Markuksen yksityisessä kodissa vieraan ja isännän positioiksi (esim. Juhila ym. 2016), kun Markus toivottaa työntekijän tervetulleeksi ja tämän vastaavasti kehuessa kotia kivaksi. Markus vastaa kohteliaisuuteen kertomalla asuneensa asunnossa jo kohtuullisen kauan ja yrittäneensä pitää siitä huolta. Kertoman tää on ihan täysin mun itte sisustama ja kaikkee avulla hänen on mahdollista korostaa henkilökohtaista panostaan kotinsa viihtyvyyden luomisessa. Henkilökohtaiseksi ja viihtyisäksi mieltyvän kodin tilan voi tulkita olevan Markuksen näkökulmasta katkaisuhoidon onnistumista tukeva elementti. Vierasisäntä-positiot korostuvat uudelleen työntekijän huomioidessa kodin fyysiset elementit kysyessään, mihin hän voi istua ja tiedustellessaan, saako hän ottaa Markukselta paperia sen sijaan, että hän toimisi asiakkaan hallitsemassa tilassa omavaltaisesti. Keskustelusta huokuu kunnioitus asiakkaan henkilökohtaista tilaa ja sen materiaalisia elementtejä kohtaan, mikä samalla muuttaa perin- teisiä työntekijän ja asiakkaan välisiä asetelmia ja vahvistaa kodin sensitiivisyyttä katkaisuhoidon tilana. Aineistossamme työntekijöiden tekemä kodin kommentointi liittyy usein sen viihtyisyyteen ja esineisiin, joiden tarinoita asiakkaat taustoittavat kertomalla omista kiinnostuksen kohteistaan tai tavaroiden merkityksellisyydestä itselleen. Kuten tässäkin esimerkissä, keskustelut kodista etenevät usein luontevasti kohti kotikatkon keskeisintä tehtävää, juomisesta puhumista.

Merkityksellisten esineiden, kuten valokuvien, koriste-esineiden, käsitöiden tai huonekalujen, kommentoinnin myötä asiakkaan persoona, taidot, historia ja sosiaaliset suhteet avautuvat konkreettisesti nähtäväksi osaksi katkaisuhoidon kohtaamisia. Tulkitsemme esineiden ja kotiympäristön toimivan eräänlaisina "jäänmurtajina" sensitiivisen kotikatkokohtaamisen äärellä. Lisäksi esineiden merkitykset voivat olla syy siihen, miksi kodista ylipäätään muodostuu katkaisuhoidolle turvallinen ja vieroittautumista tukeva sekä kulttuuriselta ja henkilökohtaiselta häpeältä suojaava tila (myös Vesa ym. 2017). Seuraavassa esimerkissä Kaisa kuvaa kodin tarjoamaa suojaa itseinhon kautta. Hän ollut raittiina ensimmäisestä kotikatkokäynnistä alkaen ja edellisestä työntekijän vierailusta on jo viikkoja aikaa.

Työntekijä: Juu, kun sä et oikein innostu$n u$ siitä, et sä oisit sinne meidän laitospalveluihin tullu, meille sinne sisään.

Kaisa: En nii.

Työntekijä: Se oli yks vaihtoehto, mutta et sä kokenu sitten, et sit kun tarjottiin tätä et voitas tulla kotiin niin siitä sä tykästyit, siihen tykästyit et se tuntu hyvältä. 
Kaisa: Niin kun mä aattelin just sitä, et mitä sitten jos emmä jaksakaan (-), et kun mulla oli se lähteminen ja nouseminen, on se vieläkin vaikeeta, mut sillon oli tosi vaikeeta kun se itseinho oli niin suuri, semmonen, eikä viittiny oikein mennä muuta kun pimeellä tonne ihmisten ilmoille sitten, ja kaupassa käymään yhtäkkiä. Kioskilta haki sitten jotain maitoo kun ei (-), tai uskaltanu eikä (-) kauppaankaan mennä, eikä jaksanu.

Kaisalle on tarjottu joko laitosmuotoista katkaisuhoitoa ja päihdekuntoutusta tai kotikatkoa. Laitoshoito ei ole häntä innostanut, mutta kotikatkon hän on mieltänyt hyväksi vaihtoehdoksi. Kaisa avaa syitä valinnalleen, sille, miten koti katkaishoidon tilana tukisi hänen vieroittautumistaan laitosympäristöä paremmin. Hän kertoo juomisputken jälkeisistä tunteistaan ja väsymyksestään. Lähteminen ja nouseminen oli vaikeaa, ulos saattoi mennä itseinhon vuoksi vain pimeällä ja silloinkin viipyä mahdollisimman lyhyen aikaa. Lisäksi julkisiin hoito- ja muihin paikkoihin lähteminen ja nouseminen vaativat uskallusta ja jaksamista, jotka tulkinnassamme näyttäytyvät Kaisalta puuttuvina voimavaroina. Työntekijän ehdottama voitas tulla kotiin muodostuu ratkaisuksi tilanteeseen ja kodin seinien sisälle jääminen keinoksi hallita itseinhoa ja jaksamattomuutta. Tällä tavoin Kaisan kodista elementteineen tulee katkaisuhoitoa tukeva, turvalliseksi määrittyvä, asukkaansa emotionaalista kiinnittymistä ilmentävä ja siten ensisijainen tila hoidon toteuttamiselle (ks. myös Stockwell ym. 1990, 65-66).

Silti kodin turvalla on myös kääntöpuolensa (esim. Granfelt 1998), jotka haastavat katkaisuhoidon toteuttamista kodin tilassa. Kotikatkon ja kodin fyysisyyden yhteydessä tämä merkitsee paitsi sitä, että koti näyttelee tilaa, jossa alkoholia pääsääntöisesti juodaan, myös paikkaa, joka esineineen ja niihin liittyvine muistoineen voi laukaista halun juoda. Siten koti voi toisinaan altistaa retkahtamiselle. Seuraavassa esimerkissä käsitellään leskeksi jääneen Teuvon tilannetta, jonka alkoholin käyttö on lisääntynyt puolison menehtymisen jälkeen. Kyseessä on neljäs kotikatkokäynti.

Työntekijä2: Mut se on toisaalta aika hieno tilanne, että se on kääntyny siihen että siitä nauttii jo siitä $y k s i n$, siitä rauhallisuudesta ja voi, ettei siihen liity ahdistusta tai ikävää tunnetta. Että sen sietää ja pystyy olemaan niiden omien ajatusten kanssa ja sen oman, ihan ittensä kanssa.

Teuvo:Joo. Kyllä se silloin alkuun se oli, ne oli pitkiä päiviä jos vaan joutu olee yksin. Ja varsinkin just ne illat.

Työntekijä2: Joo.

Teuvo: Mut en tiiä, kai siihen rupee oppimaan.

Työntekijä2: Aika tekee tehtävänsä. On asioita mitä ei tietenkään koskaan, poistu mielestä eikä sillä tavalla tietenkään palaa ennalleen mutta siis se, että sitä oppii elämä̈n niitten asioitten kanssa.

Teuvo: Kyllä.

Työntekijä2: Et toki se, yksin oleminen on, sen opettelu uudelleen niin se on varmasti haasteellista.

Teuvo:Joo.

Työntekijä2: Ei voi olettaakaan, että se tapahtus tosta vain yks kaks.

Teuvo: Näin on.

Työntekijä2: Ilman suurempia mutkia tai muuta.

Teuvo: Se on ainoo, kun mä yleensä sit vahtaan jotain tel-, tai aina vahtaan telkkarii, niin sit ku tulee joku semmonen kohta, 
et siitä vois puhuu jonkun kanssa, niin sillon tulee sitten mieleen.

Työntekijä1:Joo, ku ei ookaan ketään jolle sitten...

Teuvo: Nii.

Työntekijä1: ...puhua sitä. Kyl varmasti.

Työntekijät ja Teuvo keskustelevat, kuinka aika on auttanut Teuvon kokemaan yksinäisyyteen puolison kuoltua ja miten yksinäisyys on vaikuttanut Teuvon tunnekokemukseen kotinsa sosiaalisista elementeistä. Työntekijä toteaa, kuinka tilanne on kääntyny siihen että siitä nauttii jo siitä $y k s i n$, siitä rauhallisuudesta ja voi, ettei siihen liity ahdistusta tai ikävää tunnetta. Toteamuksen myötä Teuvon kodin voi tulkita määrittyvän vähitellen katkaisuhoitoa haastavasta ja ahdistusta tuottavasta tilasta kohti sen onnistumista tukevaa ja nautintoa tuottavaa ympäristöä. Teuvo vahvistaa oletuksen ja vastaa viittaamalla aikaisemmin kokemaansa yksinäisyyteen, kun arkea koossa pitänyt ihmissuhde olikin poissa: ne oli pitkiä päiviä jos vaan joutu olee yksin. Ja varsinkin just ne illat. Esimerkki tekee näkyväksi, kuinka yksinäisyys ja ahdistus ovat sidottuja kodin autonomisesti hahmottuvaan aikaan (Douglas 1991): pitkät päivät ja illat ahdistavat, mutta ajan kuluessa sitä pystyy olemaan niiden omien ajatusten kanssa. Työntekijä toteaa yksin olemisen olevan haasteellista ja vaativan aikaa. Teuvo havainnollistaa yksinäisyyden tunnettaan viittaamalla televisioon esineenä, jonka vahtaamisen aikana hän tulee helposti tietoiseksi yksin olosta koska, sit ku tulee semmonen kohta et, siit vois puhuu jonkun kans ni, sillon tulee sitte mieleen. Yksin oleminen ja puolison kuoleman todellisuus, havainto sosiaalisten suhteiden kaventumisesta, rakentuvat kodin seinien sisällä suhteessa arkiseen rutiiniin ja televisioon esineenä.

Teuvon koskettava kertoma havainnollistaa kotiympäristön synnyttämät ja sisälleen sulkemat herkät tilanteet ja tekee näkyväksi henkilökohtaisten tunteiden ja muistojen käsittelemisen merkityksen tilassa, joka esineineen aiheuttaa halua juoda. Näin koti voi muodostua katkaisuhoitoa haastavaksi tilaksi ja kodissa koettu yksinäisyys sitä haastavaksi tunteeksi. Toisaalta aineistomme sisältää myös muunlaisia kuvauksia negatiivisista tunnetiloista, jotka altistavat juomiselle kotona. Tällöin syyt eivät ehkä niinkään liity kodin esineisiin kuin elämäntilanteeseen ja arjen sisältöihin tai sen puutteeseen yleensä, kuten Markus asian ilmaisee: Ja kun mul on nyt ollu vähän tylsää ja vähän surullista ja pimeetä, niin se on se pullo se kaveri.

\section{Koti ja päihdetyön käytännöt}

Aineistossamme kodin tilan institutionalisoituminen tulee näkyväksi, kun siellä toteutetaan perinteisesti laitoskatkaisuhoitoon kuuluvia käytäntöjä: kysytään alkoholin käytöstä, tarkistetaan lääkityksiä, mietitään laboratoriokokeiden tarpeellisuutta ja tuloksia, puhallutetaan tai kartoitetaan sosiaalista tukiverkostoa. Tällainen toiminta on kiinteä osa kotikatkoa (Stockwell ym. 1990; Fleeman 1997, 650-651). Koti asiakkaan hallitsemana tilana kuitenkin muuttaa institutionaalisten tekojen luonnetta. Seuraavassa esimerkissä fokuksessa ovat rutiininomaiset päihdetyön käytännöt, puhalluttaminen sekä alkoholinkäytöstä keskusteleminen. Kyseessä on ensimmäinen kotikatkokäynti Markuksen luokse. 
Työntekijä: Mitä mieltä sä oot tarvisko sun puhalluttaa, vai ooks ollu ihan juomatta? Markus: Mä oon ollu nyt ihan juomatta pari päivää. Tää on nyt sit kolmas päivä ilman mitään...

Työntekijä: Joo. Mimmost se sinun alkoholinkäyttös on ollu?

Markus: Mä oon nyt ainaki viimisen puolen vuotta, juonu iltasin noin... noin kuudesta kymmeneen, kuudesta kymmeneen annosta, tai siis tölkkiä alkohol-, tai olutta, olutta pelkästään, mä en juo väkeviä. Mutta... ja se on yleensä mulla se raja se kymmenen, joskus kakstoista, jollon mä sit sammunu. Elikkä mä oon joka ilta siis vetänyt itseni semmoseen kuntoon, et mä en oo voinut juoda enempää.

Työntekijä: Just, okei, käyksä ostamassa kaupan olutta vai käyks sä oikein viinakaupassa?

Markus: Käyn ostamassa kaupan olutta, viinakaupassa mä tosi harvoin käyn. Sielläki tulee joskus käytyä, mut tosi harvoin.

Laitoskatkaisuhoidolle ominainen, juomisen kontrollointiin perustuva perusrutiini saa kodin ympäristössä hienovaraisen sävyn työntekijän kysyessä Mitä mieltä sä oot tarvisko sun puhalluttaa,johon Markus vastaa olleensa juomatta kolmisen päivää. Työntekijän kysymysmuotoinen kommentti viittaa puhalluttamisen vapaaehtoisuuteen, asiakkaan oikeuteen olla valitsematta sitä. Otteesta ei selviä, puhallutetaanko asiakasta lopulta ollenkaan, mutta esimerkki antaa olettaa, että päihdetyöhön usein kiinteästi kuuluva peruskäytäntö tulee nyt neutraalisti ohitetuksi. Tämä voidaan mieltää merkiksi siitä, kuinka instituutionaalisten sääntöjen ylläpitäminen kodin tilassa muuttuu ja asiakkaan vastuu ja autonomia korostuvat. Aineistossamme on kuitenkin myös esimerkkejä tilanteista, joissa asiakas myöntyy kodissaan puhalluttami- selle, joskaan sitä ei tällöinkään aseteta edellytykseksi kotikatkon jatkumiseksi, vaan päätöksen puhalluttamisesta tekee asiakas itse.

Puhallutuskeskustelun jälkeen siirrytään toiseen päihdetyölle ominaiseen käytäntöön, keskusteluun alkoholinkäytön luonteesta ja kulutuksesta. Keskustelu juomisesta liitetään kodin fyysiseen lähiympäristöön, kuten ruoka- tai viinakaupassa käyntiin: Käyn ostamassa kaupan olutta, viinakaupassa mä tosi harvoin käyn. Sielläki tulee joskus käytyä, mut tosi harvoin. Markuksen kertoma todentaa, kuinka kodista lähiympäristöineen muodostuu yhtäältä katkaisuhoitoa haastava, toisaalta sitä tukeva ympäristö. Vapaus ostaa kaupasta alkoholia tuo Markukselle itsenäistä vastuuta, mikä voi aiheuttaa riskejä katkaisuhoidolle. Toisaalta kodin tilan tarjoama mahdollisuus määrittää itse hoitokäytäntöjä luo Markuksen katkaisuhoidolle kontrollivapaita ja hänen itsemääräämisoikeuttaan kunnioittavia toimintatapoja.

Perinteiset katkaisuhoidon institutionaaliset säännöt tulevat puretuiksi myös seuraavan esimerkin yhteydessä, jossa alkoholin säilyttämiseen kotona ei ole tarvetta puuttua. Teuvo on ollut raittiina ensimmäisestä kotikatkokäynnistä alkaen ja työntekijät ovat tekemässä hänen luokseen kolmatta käyntiä.

Työntekijä: Onks sulla pitkään semmonen olo [että tekee mieli juoda] kun sä tuut kotiin vai meneeks se sitten kuinka nopeesti ohitte?

Teuvo: Ei kyl se sit menee ohitte.

Työntekijä: Eikä ole ajatus niin sanotusti jatkojalostunu siinä, että kun tulee se ajatus mieleen ja tulee vähän se halu niin tulee 
mieleen et no, jos kävisin hakemassa yhden pullon?

Teuvo: Ei. Mulla on jääkaapissa kolme.

Työntekijä: Okei [naurahtaa].

Teuvo: Ja ne on ollu siellä sitten jonkun aikaa.

Työntekijä ja Teuvo keskustelevat Teuvon mieliteosta juoda olutta päivän päätteeksi palattuaan kotiin. Työntekijä kysyy, onko juomahalu niin voimakas, että alkoholia tekisi mieli lähteä erikseen hakemaan. Teuvon vastaukset Ei. Mulla on jääkaapissa kolme sekä Ja ne on ollu siellä sitten jonkun aikaa kertovat keskustelun sitomisesta kodin konkreettisiin materiaalisiin elementteihin, jääkaappiin ja sieltä löytyviin pulloihin, mikä viittaa siihen, että hänellä on alkoholia kotonaan katkaisuhoidon aikana. Laitoskatkon kontekstissa alkoholin hallussapito olisi oletettavasti sääntöjen vastaista, mutta kotikatkon yhteydessä tilanne ei aiheuta työntekijän taholta kontrolloivia toimia. Tämä osoittaa, kuinka koti on asukkaansa hallitsema se venyttää institutionaalisia käytäntöjä ja luo niiden joustavuudelle sopivan tilan. Asiakkaan vapaus tehdä itse päätös alkoholin säilyttämisestä kodissaan voi Markuksen esimerkin tavoin luoda haasteita katkaisuhoidon onnistumiselle lisätessään retkahtamisriskiä. Toisaalta kotikatkon myötä Teuvolla on mahdollisuus vähentää juomistaan osana "tavallista" arkeaan ja sen "houkutuksia", johon hänen tulisi joka tapauksessa sopeutua myös laitoshoidon jälkeen. Tällä tavoin kotiympäristö voi tukea Teuvon sopeutumista arkeensa juomisen lopettamisen tai vähentämisen jälkeen. Esimerkki myös purkaa olettamia siitä, kuinka päihdetyöntekijät ylipäätään voisivat toimia tahoina, joilla on valtaa estää kansalaisten alkoholin käyt- tö. Aihe nousee puheenaiheeksi työntekijöiden ja Teuvon välisessä keskustelussa uudelleen:

Teuvo: Joo mä ajattelin sillon, ette ollu käynytkään vissiin vielä, en mä oikein muista mimmonen juttu se oli, mut mä sitä sit ittekseni ajattelin, et miten te sitten vahditte etten mä ota viinaa.

Työntekijä1: Mehän emme vahdi, koska se on nimenomaan, vastuu ja kaikkihan on kuitenkin niinku sinulla, ja et mehän ollaan vain se, me annetaan niin paljon tukea kuin me voidaan ja sit tsempataan siinä että, eihän, me ei olla asennettu tänne kameroita eikä muuta [naurahtaa].

Työntekijä2: Ei salakuunnella eikä mitään [naurahtaa]. Me ollaan ihan sen varassa mitä sä meille kerrot.

Työntekijä1: Ja se se varmaan onkin se pointti tässä, et kuitenkin niinku...

Teuvo: Mut niinku siellä katkolla niin, siellähän ei saa olla viinaa.

Työntekijä1: Ei tietenkään.

Teuvo kertoo pohtineensa ennen kotikatkon ensimmäistä käyntiä, kuinka työntekijät vahtisivat, ettei hän joisi kotonaan. Lausahdus yhdistää kotikatkoon vahvan institutionaalisen kontrolliolettaman, jonka työntekijä kumoaa kommentoidessaan, kuinka vastuu ja kaikkihan on kuitenkin niinku sulla ja todetessaan, että eihän me olla asennettu tänne kameroita eikä muuta. Kotikatkon työntekijöiden puheesta voidaan tulkita, etteivät tietyt julkisille instituutioille ominaiset, kontrolliin perustuvat materiaaliset esineet, tässä tapauksessa valvontakamerat, kuulu kodin yksityiseen ja asukkaansa autonomian alaiseen tilaan. Kotikatkosta muodostuu tuki ja tsemppi, jonka pointti on luottamus ja se, mitä Teuvo itse tilanteeltaan haluaa. Esimerkin lopussa selväksi tulee myös 
se, kuinka samat säännöt eivät päde kotona ja laitoksessa, kun Teuvo edelleen vetoaa kontrolliin kommentoidessaan Mut niinku siellä katkolla, niin siellähän ei saa olla viinaa. Tähän työntekijä vastaa Ei tietenkään, tehden kotiympäristön erityisyyden asiakkaan autonomian näkökulmasta suhteessa perinteisiin institutionaalisiin käytäntöihin näkyväksi. Kodin ympäristössä asiakkaan vastuu katkaisuhoidon onnistumisesta ja omasta hyvinvoinnistaan muodostuu ensisijaiseksi.

Kotiympäristö aiheuttaa aineistossamme haasteita kotikatkolle ja painetta päihdetyön käytännöille silloin, kun työntekijät tarvitsisivat käyttöönsä laitoksen tarjoamia fyysisiä työvalineitä, kuten tulostimia, tietojärjestelmiä tai konsultaatioapua lääkehoidon kysymyksissä. Lisäksi katkaisuhoidon toteuttaminen kotona saattaa herättää asiakkaissa mietteitä siitä, mitä naapurit ajattelevat (Sockwell ym. 1990) ja ainakin ajoittaista huolta siitä, onko vapauden tuoma vastuu omasta raittiudesta liian painavaa kantaa. Silti tässä esitetyt esimerkit osoittavat, että vaikka perinteisemmät päihdetyön käytännöt hakevat kodin ympäristössä uusia muotoja, niiden murtuminen vapauttaa työntekijöitä institutionaalisten olettamien taakasta luoden katkaisuhoidolle kontrollivapaan ja asiakaslähtöisyyttä tukevan tilan.

\section{ЈонтОРёÄтÖKSET}

Tässä artikkelissa olemme etsineet vastausta kysymykseen siitä, miten koti tilana tukee ja haastaa psykososiaalisesti orientoituneen katkaisuhoidon käytäntöjä ja asiakaskohtaamisia. Olemme tehneet tulkintoja siitä, mitä institutionaalisesti määrittyvässä katkaisuhoidossa tapahtuu, kun se viedään kodin yksityiseen ja monimerkitykselliseen tilaan, joka ilmentää konkreettista asumista, elämänhistorioita, tunteita sekä kulttuurisia, sosiaalisia ja moraalisia järjestyksiä (Douglas 1991). Empiirinen analyysimme havainnollistaa, kuinka koti elementteineen kietoutuu osaksi asiakas-työntekijäkohtaamisia tukien ja haastaen katkaisuhoidon käytäntöjä, tarjoten perinteisempiin katkaisuhoitoolosuhteisiin nähden asiakas-työntekijävuorovaikutukselle ja katkaisuhoidon toteuttamiselle uudenlaiset, asiakkaan henkilökohtaiseen arkeen kietoutuvat puitteet.

Kodin materiaaliset ja emotionaaliset, tilan henkilökohtaisuutta ilmentävät elementit tukevat vuorovaikutuksen käynnistymistä, syventävät ja personoivat asiakas-työntekijäkohtaamisten luonnetta, tuottavat turvallisuutta ja vapauttavat työntekijöitä institutionaaliseen toimintaan liittyvästä kontrollitehtävästään, kun vuorovaikutus tapahtuu asiakkaan hallitsemassa yksityisessä tilassa. Silti kotiympäristö monine merkityksineen ja esineineen aktivoi myös negatiivisia tunnetiloja, jolloin koti tuen sijaan saattaa merkitä lähtölaukausta juomiselle (ks. myös Fleeman 1997, 654-655).Tämän lisäksi koti materiaalisine, sosiaalisine, fyysisine ja emotionalisine elementteineen edellyttää kotikatkon asiakkailta ja työntekijöitä kykyä asettua positioihin, joissa institutionaalisille kohtaamisille perinteiset vastuu- ja kontrolliasemat muuttuvat (ks. myös Juhila ym. 2016). Kodin tilassa laitosolosuhteissa rutiininomaisesti toteutetut päihdetyön käytännöt ja säännöt murtuvat ja vas- 
taavasti asiakkaan vastuu omasta hyvinvoinnistaan sekä mahdollisuus käyttää itsemääräämisoikeuttaan ja vaikuttaa katkaisuhoidon institutionaalisiin käytäntöihin korostuvat.

Tutkimuksemme osoittaa, kuinka koti haastaa perinteisen näkemyksen katkaisuhoidosta ja laajentaa käsitystä siitä, miten ja missä katkaisuhoitoa voidaan toteuttaa (ks. myös Bischof ym. 2003). Koti on katkaisuhoidon yhteydessä tila, joka tulee konkreettisesti ja kokonaisvaltaisesti läsnäolevaksi asiakkaiden ja työntekijöiden väliseen vuorovaikutukseen. Kohtaamiset kodissa havainnollistavat, missä, miten ja millaisessa sosiaalisessa ympäristössä asiakas elää ja millaisia juomisen lopettamista tukevia tai haastavia tekijöitä hänen henkilökohtaisesta arjestaan, kodistaan tai sen lähiympäristöstä voidaan paikantaa hän istuu tässä, käy kaupassa tuolla, on tehnyt tämän omin käsin tai jakaa arkeaan hänen tai heidän kanssaan. Tällaisten konkreettisten, elinympäristöstä ja sen merkityksistä kertovien havaintojen tekeminen ei laitosolosuhteissa ole mahdollista.

Kodin tilassa päihteiden käyttö ja katkaisuhoito henkilökohtaistuvat saadessaan merkityksensä suhteessa elämänhistoriaan, tunteisiin, ihmissuhteisiin ja kodin materiaalisuuteen mahdollistaen asiakkaan kokonaisvaltaisen elämäntilanteen havainnoimisen ja tukemisen. Henkilökohtaistuminen tuo katkaisuhoitoon elementin, jonka avulla sensitiiviset aiheet, kuten alkoholin käyttö, häpeä ja itseinho tai puolison kuoleman aiheuttama yksinäisyys, voidaan kohdata tilassa, jossa niiden kanssa pitäisi pystyä myös elämään. Havainto on merkityksellinen, koska laitoskatkaisus- ta kotiutuessaan ihminen palaa yleensä samaan fyysiseen tilaan, jossa juomista laukaisevat tekijät häntä edelleen odottavat (Wright ym. 2018, 388-389). Näin kotikatko tarjoaa realistisen ympäristön opetella keinoja päihteiden käytön hallitsemiseksi (Bischof ym. 2003, 23).

Tutkimuksemme tekee näkyväksi psykososiaalisen orientaation merkityksellisyyden osana katkaisuhoitoa ja päihteistä vieroittumista valaisten käsitystä siitä, miten koti monine henkilökohtaisine elementteineen on hedelmällinen ympäristö psykososiaaliselle työlle. Kokonaisvaltaisesti asiakkaan arkeen kiinnittynyt kotikatko tarjoaa lääketieteelliseen orientaatioon perustuvan "perinteisen" katkaisuhoidon rinnalle täydentävän palvelumuodon, jota on mahdollista hyödyntää esimerkiksi jatkumona laitoksessa tapahtuvalle katkaisuhoidolle. Tämä tuottaa myös yksilöllisyyttä, asiakaslähtöisyyttä ja saavutettavuutta päihdepalveluiden valikoimaan. Katkaisuhoidon kehittäminen koteihin vietäviksi palveluiksi tarjoaa mahdollisuuden tavoittaa päihdepalveluiden piiriin herkästi niiden ulkopuolelle jääviä ihmisiä (esim. Vesa 2017). Aikaisemmissa tutkimuksissa kotikatkon on todettu olevan hyvä vaihtoehto esimerkiksi (vuoro)työssä käyville ihmisille (Bischof 2003, 22; Carlebach 2011, 44; Nadkarni ym. 2017, 394-396). Mikäli katkaisuhoidon tarpeessa oleva ihminen on perheellinen, kotikatko tarjoaa oivallisen tilaisuuden tukea tai ohjata tarvittaviin tukipalveluihin myös läheisiä (Fleeman 1997, 654; Bischof 2003). Esimerkiksi samassa taloudessa asuvilla alaikäisillä lapsilla voi ilmetä tarvetta lapsiperheiden sosiaalityölle tai muulle tuelle van- 
hemman runsaan päihteiden käytön vuoksi.

Vaikka tutkimuksemme tekee näkyväksi kodin tilan vahvuuksia katkaisuhoidon ympäristönä, se herättää myös kriittisiä kysymyksiä. Kodin tilasta tulee katkaisuhoidolle haaste silloin, jos siellä kannettava vastuu oman tilanteensa hallinnasta muuttuu asiakkaalle ylivoimaiseksi eikä ympärivuorokautista ammatillista tukea ole laitosympäristön tavoin tarjolla - jos oluet eivät säilykään jääkaapissa, aika ei autakaan ahdistukseen tai pullo tarjoaa raittiutta parempaa seuraa iltaisin. Eila Vesan ja kollegoiden (2017) tutkimuksessa ikääntyneet päihteitä käyttävät naiset kokivat, ettei kukaan ottanut heistä vastuuta. Tämä tutkimus havainnollistaa, kuinka kotikatko palvelumuotona edellyttää asiakkaalta kykyä ottaa vastuuta juomisensa kontrolloinnista. Havaintomme on linjassa aikaisempien tutkimusten kanssa, joissa kotikatkon todetaan soveltuvan hyvin motivoituneille, suhteellisen hyväkuntoisille ja turvallisessa ympäristössä eläville asiakkaille (Fleeman 1997, 655; Nadkarni 2017). Näin vastuu saa kotikatkon yhteydessä kahtalaisen aseman sen ollessa yhtä aikaa sekä työntekijöiden osoittama luottamuksen ele että katkaisuhoidon onnistumisen vaatimus. Kotiympäristö voikin haastaa katkaisuhoidon toteuttamista, jos asiakkaan motivaatio on hukassa ja hänellä on sen vuoksi tarvetta intensiivisemmälle tuelle, fyysinen tai henkinen terveys huono ja vieroitus vaatii siksi ympärivuorokautista seurantaa tai kodin elinympäristö on turvaton. Turvattomuutta kotiin voivat tuottaa esimerkiksi juova naapurusto sekä jännitteiset tai väkivaltaiset läheissuhteet (Fleeman 1997, 650). Kärjistetysti kotikatkoa on mahdollista kritisoida myös normatiivisesta olettamuksesta, jonka mukaan ihmisellä ylipäätään on olemassa koti, jonne palvelua voidaan viedä. Tässä mielessä päihdepalveluja kehitettäessä onkin hyvä pitää mielessä, että myös kodittomat, tilapäisasumista tarjoavissa yksiköissä tai jonkun luona majailevat ihmiset tarvitsevat jalkautuvia tukimuotoja raittiutensa tueksi. Lisäksi harvakseltaan toteutettavien psykososiaalisesti orientoituneiden kotikatkokäyntien yhteydessä on mahdollista kysyä, missä vaiheessa katkaisuhoito muuttuu kuntouttavaksi työskentelyksi.

Lopuksi on hyvä todeta, ettei aineistomme mahdollista tulosten yleistämistä kodin tilan hyödyistä ja haitoista esimerkiksi lääketieteellisesti orientoituneen ja toimintatavoiltaan perinteisemmäksi mielletyn katkaisuhoidon ympäristönä. Tarkka empiirinen analyysi kuitenkin osoittaa, kuinka kodilla katkaisuhoidon toteuttamisen tilana on vahva merkitys osana asiakastyöntekijävuorovaikutusta ja sillä on vaikutuksensa myös katkaisuhoidon institutionaalisiin käytäntöihin. Kodin kynnyksen ylittämisen myötä kotikatkoa toteuttavat asiakas ja työntekijä asettuvat kulttuuristen, sosiaalisten, moraalisten, materiaalisten, emotionaalisten ja institutionaalisten järjestysten ristiaallokkoon, joka paitsi ohjaa heidän toimintaansa, auttaa myös kyseenalaistamaan sitä. Tässä mielessä kotikatkoa ja sen aikana tapahtuvaa asiakas-työntekijävuorovaikutusta on tarpeen tutkia lisää.

\section{VIITE}

1 Artikkelin aineistonkeruusta on vastannut 
Suvi Holmberg. Tutkimukseen osallistui yhteensä neljä työntekijää, jotka työskentelivät joko yksin tai pareittain. Työntekijöiden ammattinimikkeet vaihtelivat ohjaajasta sairaanhoitajaan.

\section{KiRjallisuUs}

Alwyn, Tina \& John, Bev \& Hodgson, Ray J. \& Phillips, Ceri J. (2004) The addition of a psychological intervention to home detoxification programme. Alcohol \& Alcoholism 39 (6), 536-541. https://doi. org/10.1093/alcalc/agh092

Babor, Thomas F. \& Stenius, Kerstin \& Römelsjö,Anders (2009) Päihdehuollon järjestelmät kansanterveyden näkökulmasta. Teoksessa Tuukka Tammi, Mauri Aalto \& Anja Koski-Jännes (toim.) Irti päihdeongelmista:Tutkimuksia hoidon ja ehkäisyn menetelmistä. Helsinki: Edita, 195-216.

Bischof, Gary H. \& Richmond, Christopher J. \& Case, Alicia R. (2003) Detoxification at home:A brief solution-oriented family systems approach. Contemporary Family Therapy 25 (1), 17-39. https:// doi.org/10.1023/A:1022553920603

Blunt, Alison (2005) Cultural geography: Cultural geographies of home. Progress in Human Geography 29 (4), 505-515. https://doi. org/10.1191/0309132505ph564pr

Büscher, Monica \& Urry, John (2009) Mobile methods and the empirical. European Journal of Social Theory 12 (1), 99-116. https://doi. org/10.1177/1368431008099642

Carlebach, Sarit \& Wake, Dominic \& Hamilton, Sharon (2011) Experiences of home detoxification for alcohol dependency. Nursing Standard 26 (10), 41-47. https://doi.org/10.7748/ns.26.10.41. s50

Douglas, Mary (1991) The idea of home: A kind of a space. Social Research 58 (1), 287-307.

Dyck, Isabell \& Kontos, Pia \& Angus, Jan \& McKeever, Patricia (2005) The home as a site for long-term care: Meanings and management of bodies and spaces. Health \& Place 11 (2), 173-185. https://doi. org/10.1016/j.healthplace.2004.06.001
Ferguson, Harry (2016) Researching social work practice close up: Using ethnographic and mobile methods to understand encounters between social workers, children and families. British Journal of Social Work 46 (1), 153-168. https:// doi.org/10.1093/bjsw/bcu120

Fleeman, Nigel D. (1997) Alcohol home detoxification: A literature review. Alcohol \& Alcoholism 32 (6), 649-656. https://doi.org/10.1093/oxfordjournals.alcalc.a008315

Forsberg, Hannele \& Ritala-Koskinen, Aino (toim.) (2018) Monen kodin lapset. Helsinki: Gaudeamus.

Gibbs, Graham (2007) Analyzing qualitative data. Los Angeles: Sage. https://doi. org/10.4135/9781849208574

Granfelt, Riitta (1993) Psykososiaalinen orientaatio sosiaalityössä. Teoksessa Riitta Granfelt, Harri Jokiranta, Synnöve Karvinen, Aila-Leena Matthies \& Anneli Pohjola (toim.) Monisärmäinen sosiaalityö. Helsinki: Sosiaaliturvan keskusliitto, 177-227.

Granfelt, Riitta (1998) Kertomuksia naisten kodittomuudesta. Helsinki: Suomalaisen kirjallisuuden seura.

Haahtela, Riikka \& Juhila, Kirsi (2016) Arjen valinnat ja neuvot kotikuntoutuksen kohtaamisissa. Teoksessa Kirsi Juhila \& Teppo Kröger (toim.) Siirtymät ja valinnat asumispoluilla. Jyväskylä: SoPhi, 192-214.

Hall, Christopher \& Juhila, Kirsi \& Matarese, Maureen \& van Nijnatten, Carolus (toim.) (2014) Analysing social work communication: Discourse in practice. London: Routledge. https://doi. org/10.4324/9780203084960

Hurtig, Johanna \& Laitinen, Merja (2000) Kohtalokas kolmio: Perhe, paha ja ammattilaiset. Janus 8 (3), 249-265.

Janus (2000) Koti! 8 (3).

Jokinen, Eeva (2010) Kodin, työn ja talouden uusi järjestys. Janus 18 (1), 48-60.

Juhila, Kirsi \& Hall, Christopher \& Raitakari, Suvi (2016) Interaction during mental health floating support home visits: Managing host-guest and professional-client identities in home spaces. Social \& Cultural Geography 17 (1), 101-119. https://doi.org/10.1080/14649365.201 5.1042401 
Juhila, Kirsi (2018) Aika, paikka ja sosiaalityö. Tampere:Vastapaino.

Koivisto, Janne (2018) Katkaisuhoito onnistuu myös kotona: Turun kotikatkosta hyviä kokemuksia. Turkulainen Paikalliset 22.4.2018. https://www.turkulainen. fi/artikkeli/630528-katkaisuhoito-onnistuu-myos-kotona-turun-kotikatkosta-hyvia-kokemuksia Luettu 2.5.2019.

Kuusisto, Katja \& Ranta, Johanna (2020) Psykososiaalisen päihdetyön asema Suomessa 1900-luvulta nykypäivään. Teoksessa Johanna Moilanen, Johanna Annola \& Mirja Satka (toim.) Sosiaalityön käänteet. Jyväskylä: SoPhi, 112-140.

Kuussaari, Kristiina \& Ronkainen, Emilia \& Partanen, Airi \& Kaukonen, Olavi \& Vorma, Helena (2012) Kuntoutuksesta katkaisuun: Päihdetapauslaskenta palvelujärjestelmän kuvaajana. Yhteiskuntapolitiikka 77 (6), 640-655.

Lydahl, Doris \& Holmberg, Suvi \& Günther, Kirsi \& Ranta, Johanna (2020) Doing data together: Affective relations and mobile ethnography in home visits. Qualitative Research. First Published 19 May 2020. https://doi. org/10.1177/1468794120917913

Milligan, Christine (2003) Location or dis-location? Towards a conceptualization of people and place in the caregiving experience. Social \& Cultural Geography 4 (4), 455-470. https://doi. org/10.1080/1464936032000137902

Mustonen, Heli \& Österberg, Esa (2010) Missä juodaan? Alkoholinkäyttö kotija anniskeluympäristössä. Teoksessa Pia Mäkelä, Heli Mustonen \& Christoffer Tigerstedt (toim.) Suomi juo: Suomalaisten alkoholinkäyttö ja sen muutokset 1968-2008. Helsinki: Terveyden ja hyvinvoinnin laitos, 70-84.

Nadkarni, Abjihit A. \& Endsley, Paige \& Fuhr, Daniela \& Noorani, Aneesa \& Naik, Aresh \& Murthy, Pratima \& Velleman, Richard (2017) Community detoxification for alcohol dependence: A systematic review. Drug and Alcohol Review 36 (3), 389-399. https://doi. org/10.1111/dar.12440

Novoa, Andre (2015) Mobile ethnography: Emergence, techniques and its importance to geography. Human Geographies: Journal of Studies and Research in $\mathrm{Hu}-$ man Geography 9 (1), 97-107. https:// doi.org/10.5719/hgeo.2015.91.7

Pesonen, Esa (2010) Kotikatko löysi ikääntyneet asiakkaikseen. Tiimi 5/2010. https://a-klinikkasaatio.fi/tiimi/1099/ kotikatko-loysi-ikaantyneet-asiakkaikseen Luettu 2.5.2019.

Raitakari, Suvi \& Holmberg, Suvi \& Juhila, Kirsi \& Räsänen,Jenni-Mari (2018) Constructing the elements of the "recovery in" model through positive assessments during mental health home visits. International Journal of Environmental Research and Public Health 15 (7). https:// doi.org/10.3390/ijerph15071441

Raitakari, Suvi \& Juhila, Kirsi (2016) Asumispolkujen tutkimisen lähtökohdat ja menetelmät. Teoksessa Kirsi Juhila \& Teppo Kröger (toim.) Siirtymät ja valinnat asumispoluilla. Jyväskylä: SoPhi, 40-59.

Ranta, Johanna \& Juhila, Kirsi (2020) Constructing a sense of home in floating support for people using drugs. Qualitative Social Work 19 (4), 685-700. https:// doi.org/10.1177/1473325019847262

Roche,Ann M. \& Watt, Kerianne \& Fischer, Jane (2001) General practitioners' views of home detoxification. Drug \& Alcohol Review 20 (4), 395-406. https://doi. org/10.1080/09595230120092788

Samposalo, Hanna \& Kuussaari, Kristiina \& Hirschovits-Gerz, Tanja \& Kaukonen, Olavi \& Partanen, Airi \& Vorma, Helena (2018) Tarpeenmukaiset palvelut kaikille? Päihdeasiakkaat sosiaali- ja terveydenhuollon palveluissa Kaakkois-Suomen ja Lapin alueilla. Yhteiskuntapolitiikka 83 (1), 50-61.

Stockwell, Tim \& Bolt, Liz \& Milner, Ingrid \& Pugh, Peter \& Young, Ian (1990) Home detoxification for problem drinkers: Acceptability to clients, relatives, general practitioners and outcome after 60 days. British Journal of Addiction 85 (1), 61-70. https:// doi.org/10.1111/j.1360-0443.1990. tb00624.x

Terveyden ja hyvinvoinnin laitos (2018) Päihdetilastollinen vuosikirja 2018: Alkoholi ja huumeet. Helsinki: Terveyden ja hyvinvoinnin laitos.

Toikko, Timo (1997) Psykososiaalinen lähestymistapa sosiaalityössä. Janus 5 (2), 
169-188.

Tuominen, Esa (2014) Katkaisuhoito tulee kotiin. Lääkärilehti, Ajassa- Ajankohtaista 12.6.2014. https://www.laakarilehti.fi/ ajassa/ajankohtaista/katkaisuhoito-tuleekotiin/Luettu 2.5.2019.

Vesa, Eila \& Orjasniemi, Tarja \& Skaffari, Pia (2017) Ikääntyvien päihdeongelmaisten naisten tuen tarpeet ja kotiin jalkautuvan päihdetyön mallin kehittäminen. Gerontologia 31 (1), 23-37.

Vilkko, Anni (2000) Riittävästi koti. Janus 8 (3), 213-230.

Vilkko, Anni \& Suikkanen, Asko \& Järvinen-Tassopoulos, Johanna (toim.) (2010) Kotia paikantamassa. Rovaniemi: Lapin yliopistokustannus.

Warpenius, Katariina \& Mäkelä, Pia (2018) Missä suomalaiset juovat? Alkoholinkäyttö koti- ja anniskeluympäristössä.
Teoksessa Pia Mäkelä, Janne Härkönen, Tomi Lintonen, Christoffer Tigerstedt \& Katariina Warpenius (toim.) Näin Suomi juo: Suomalaisten muuttuvat alkoholinkäyttötavat. Helsinki:Terveyden ja hyvinvoinnin laitos, 112-124.

Weckroth, Antti (2007) Mitä merkitsee "psykososiaalinen" päihdehoidossa? Yhteiskuntapolitiikka 72 (4), 426-436.

Wright, Cameron M. \& Norman, Richard \& Varhol, Richard \& Davis, Jacqueline \& Wilson-Taylor, Elizabeth \& Dorigo, Justin \& Robinson, Suzanne (2018) Exploring the costs and effectiveness of the drug and alcohol withdrawal network: A home-based alcohol and other drug withdrawal service. Australian Journal of Primary Health 24 (5), 385-390. https:// doi.org/10.1071/PY17110 